\title{
Synthesis and neuropharmacological evaluation of some new isoxazoline derivatives as antidepressant and anti-anxiety agents
}

\author{
Jagdish Kumar ${ }^{1}$, Gita Chawla ${ }^{1 \star}$, Himanshu Gupta ${ }^{2}$, Mymoona Akhtar $^{1}$, Om prakash Tanwar $^{3}$ \\ and Malay Bhowmik \\ ${ }^{1}$ Department of Pharmaceutical Chemistry, Faculty of Pharmacy, Hamdard University, New Delhi-110062, India. \\ ${ }^{2}$ Faculty of Pharmacy, Hamdard University, New Delhi, India. \\ ${ }^{3}$ Drug Design and Medicinal Chemistry Laboratory, Hamdard University, New Delhi-110062, India. \\ ${ }^{4}$ Neuro behavioral Pharmacology Lab., Hamdard University, New Delhi-110062, India.
}

Accepted 18 April, 2013

\begin{abstract}
A series of 3-(furan-2-yl)-5-(substituted phenyl)-4,5-dihydro-1,2-oxazole derivatives (2a to j) were synthesized by Claisen Schmidt condensation of 2-acetyl furan with different types of aromatic aldehyde, as chalcones and their subsequent cyclization to 4,5-dihydro-1,2-oxazole with hydroxylamine hydrochloride. The chemical structures of the synthesized compounds were confirmed by IR, ${ }^{1} H$ NMR, ${ }^{13} \mathrm{C}$-NMR and mass spectrometric data. This study further involves evaluation of synthesized compounds for antidepressant and antianxiety activities using force swimming test (FST) and elevated plus maze method, respectively. Most of the tested compounds were found to be moderate to significant activities at the dose level of $10 \mathrm{mg} / \mathrm{kg}$, compared to reference drugs imipramine and diazepam, respectively. Compound 4-[3-(furan-2-yl)-4,5-dihydro-1,2-oxazol-5-yl]phenol (2e) emerged as the most potent antidepressant agent acting through monoamine oxidase (MAO) inhibition without any significant neurotoxicity. The molecular docking study were also carried out on the falcipain-2 receptor (PDB id: 2Z5X) for all the compounds and compound $2 e$ was found to occupy in the receptor cavity and forms hydrogen bond and hydrophobic interactions with active residues.
\end{abstract}

Key words: Isoxazoline, Claisen Schmidt condensation, antidepressant, antianxiety.

\section{INTRODUCTION}

Anxiety is a common central nervous system (CNS) disorder due to various stress factors (physiological, psychological and sociological) resulting in disturbance of daily life. Nowadays with increasing competition, anxiety has become one of the wide spread psychiatric disorder affecting around $1 / 8$ th of the total population globally consequently turned into an important area of research in psychopharmacology (Crowley and Lucki, 2005; Koksal and Bilge, 2007). Moreover, depression is also increasingly becoming ubiquitous and serious mental disease by impacting on all aspects of a person's life. The etiology of depression (Henn et al., 2004; Gartside and Cowen, 2006; Deecher et al., 2006; Sanchez, 2006) is suggested to be the dysfunction of monoamine neurotransmitters in CNS, such as serotonin (5-hydroxytryptamine, or 5-HT), dopamine (DA) and norepinephrine (NE), but the specific etiology of major depression is still far from clear (Sanchez, 2006; Huang et al., 2006; Andersen et al., 2008). 
The predominant monoamine theory (Owen and Whitton, 2006) combines depression with lowered concentrations of monoamine neurotransmitters at brain synapses. Treatment of depression thus may be achieved by restoring the monoamine levels to normal. Tricyclics (TCA), monoamine oxidase (MAO) inhibitors, selective serotonin reuptake inhibitors (SSRI), serotonine norepinephrine reuptake inhibitors (SNRI), norepinephrine dopamine reuptake inhibitors (NDRI), norepinephrine reuptake inhibitors (NRI), serotonin modulators and norepinephrine serotonin modulators are the major antidepressant drug classes used for the treatment of depressive disorders (Henn et al., 2004; Gartside and Cowen, 2006).

Nitrogen and oxygen containing five member heterocyclic compounds, have gained considerable attention due to the wide spectrum of pharmacological activi-ties. Among these, isoxazoline represents one of the most diverse bioactive moiety exhibiting a wide range of biological properties such as antidepressant, antianxiety (Gil et al., 2009; David et al., 1994; Edwin and Lilianna, 2004; Andres et al., 2007; Ignacio and Gil, 2007, 2004, 2008; Mary et al., 2011; Winters et al., 1985; Cesura et al., 1992; Amrein et al., 1999), anti-stress (Maurya et al., 2011; Andersen et al., 2008), anticonvulsant (Balalaie et al., 2000), antiviral (Lee et al., 2009), anti-inflammatory (Dannahardt et al., 2000), antiinflammatory and analgesic activities (Jayashankar et al., 2009). Several isoxazoline derivatives have also been patented as therapeutic agents having antidepressant and anxiolytic activities. Recent studies have shown that isoxazoles are good inhibitors of brain enzymes like MAO. Moreover, isocarboxazid an isoxazole derivative is an irreversible and nonselective monoamine oxidase inhibitor (MAOI) used as antidepressant and anxiolytic (Fagervall and Ross, 1986). Similarly furan nucleus finds a wide variety of bioactive applications like cytotoxicity, anti-inflammatory (Chen et al., 2006), anti-tuberculosis (Tangallapally et al., 2006), anti-tumor (Sun et al., 2010), antidepressant, anticonvulsant (Zuhal et al., 2007), and MAO inhibitors (Kelekci et al., 2009; Jayaprakash et al., 2008; Karuppasamy et al., 2010).

Therefore, in this study, the target compounds were designed keeping the isoxazole bioactive moiety with the aim that the aforementioned molecules would have promising antidepressant and antianxiety properties.

\section{MATERIALS AND METHODS}

All the chemicals used were laboratory grade and procured from $\mathrm{E}$. Merck (Germany) and S.D. Fine Chemicals (India). Melting points were determined by the open tube capillary method and are uncorrected.

The thin layer chromatography (TLC) plates (silica gel G) were used to confirm the purity of commercial reagents used, compounds synthesized and to monitor the reactions as well. Two different solvent systems: toluene:ethyl acetate:formic acid (5:4:1) and benzene:acetone $(9: 1)$ were used to run the TLC and spots were located under iodine vapors/UV light. IR spectra were obtained on a Perkin-Elmer 1720 FT-IR spectrometer (KBr Pellets). ${ }^{1} \mathrm{H}-\mathrm{NMR}$ spectra were recorded on a Bruker AC $400 \mathrm{MHz}$, spectrometer using TMS as internal standard in DMSO- $\mathrm{d}_{6}$.

\section{Chemistry}

General procedure for the preparation of 1-(furan-2-yl)-3(substituted phenyl)prop-2-en-1-one (1a to j)

A mixture of 2-acetyl furan $(0.01 \mathrm{~mol})$ and appropriate aromatic aldehydes $(0.01 \mathrm{~mol})$ in absolute methanol $(30 \mathrm{ml})$ were stirred at room temperature in the presence of base (aqueous solution of potassium hydroxide $40 \%$; $15 \mathrm{ml}$ ) till completion of the reaction. The reaction mixture was kept overnight at room temperature and then poured into crushed ice followed by neutralization with $\mathrm{HCl}$. The solid separated was filtered, dried and crystallized from ethanol. The purity of the chalcones was checked by TLC.

General procedure for the preparation of 3-(furan-2-yl)-5(substituted phenyl)-4,5-dihydro-1,2-oxazole (2a to j)

To a solution of compounds $1 \mathrm{a}$ to $\mathrm{j}(0.01 \mathrm{~mol})$ in absolute ethanol $(50 \mathrm{ml})$, it was added dry pyridine $(1 \mathrm{ml})$ and hydroxylamine hydrochloride $(0.01 \mathrm{~mol})$, and the contents was refluxed for 8 to 10 $\mathrm{h}$ and was left overnight. The solvent was evaporated and the residue was poured into cold water; the solid mass that separated out was filtered, washed with water dried and crystallized from methanol.

\section{3-(Furan-2-yl)-5-phenyl-4,5-dihydro-1,2-oxazole (2a)}

Yield 58\%; m.p. $112^{\circ} \mathrm{C}$. FTIR (KBr pellet) $\mathrm{cm}^{-1}: 1656(\mathrm{C}=\mathrm{N}), 1352$ $(\mathrm{C}-\mathrm{O}-\mathrm{N}), 1052$ (C-O-C). ${ }^{1} \mathrm{H}$ NMR (DMSO-d $) \delta$ (ppm): 7.07-8.10 $(7 \mathrm{H}, \mathrm{m}, \mathrm{ArH}), \quad 6.18(\mathrm{~m}, 1 \mathrm{H}$, (furan $\mathrm{CH}) ; 5.78\left(1 \mathrm{H}, \mathrm{m}, \mathrm{CH}_{\text {isoxazoline})}\right.$, $3.62\left(1 \mathrm{H}, \mathrm{dd}, J=11.5,5.6 \mathrm{~Hz}, \mathrm{CH}_{\text {isoxazoline }}\right), 3.59(1 \mathrm{H}, \mathrm{dd}, J=9.3$,

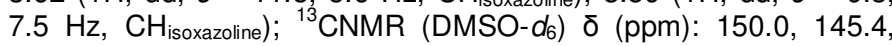
140.0, 139.4, 127.7, 126.9, 126.2, 125.3, 116.0, 115.2, 79.2, 42.9. MS: $\mathrm{m} / \mathrm{z} 213(\mathrm{M}+)$. Elemental analysis: Calculated for $\mathrm{C}_{13} \mathrm{H}_{11} \mathrm{NO}_{2}$ : C, 73.23 ; H, 5.20; N, 6.57; found: C, 73.34; H, 5.28; N, 6.62\%.

\section{5-(4-Chlorophenyl)-3-(furan-2-yl)-4,5-dihydro-1,2-oxazole (2b)}

Yield 65\%; m.p. $142^{\circ} \mathrm{C}$. FTIR (KBr pellet) $\mathrm{cm}^{-1}: 1661(\mathrm{C}=\mathrm{N}), 1356$ $(\mathrm{C}-\mathrm{O}-\mathrm{N}), 1058$ (C-O-C). ${ }^{1} \mathrm{H}$ NMR (DMSO-d $d_{6} \delta$ (ppm): 7.10-7.34 $(6 \mathrm{H}, \mathrm{m}, \mathrm{ArH}), \quad 6.08(\mathrm{~m}, 1 \mathrm{H}$, (furan $\mathrm{C}-\mathrm{CH}) ; 5.81(1 \mathrm{H}, \mathrm{m}$,

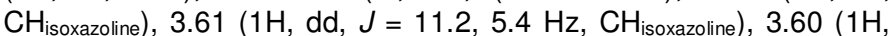
$\left.\mathrm{dd}, J=9.2,7.7 \mathrm{~Hz}, \mathrm{CH}_{\text {isoxazoline }}\right) ;{ }^{13} \mathrm{CNMR}$ (DMSO- $\left.d_{6}\right) \delta(\mathrm{ppm})$ 150.0, 145.4, 139.4, 134.6, 129.9, 129.2, 124.0, 116.0, 115.2, 79.2, 42.9. MS: $\mathrm{m} / \mathrm{z} 247\left(\mathrm{M}^{+}\right)$and $249(\mathrm{M}+2)$. Elemental analysis: Calculated for $\mathrm{C}_{13} \mathrm{H}_{10} \mathrm{CINO}_{2}$ : C, 63.04; $\mathrm{H}, 4.07 ; \mathrm{N}, 5.66$; found: $\mathrm{C}$, 63.18; H, 4.12; N, 5.72\%.

\section{5-(4-Bromophenyl)-3-(furan-2-yl)-4,5-dihydro-1,2-oxazole (2c)}

Yield 64\%; m.p. $118^{\circ} \mathrm{C}$. FTIR (KBr pellet) $\mathrm{cm}^{-1}: 1667(\mathrm{C}=\mathrm{N}), 1354$ $(\mathrm{C}-\mathrm{O}-\mathrm{N}), 1066$ (C-O-C). ${ }^{1} \mathrm{H}$ NMR (DMSO- $\left.d_{6}\right) \delta(\mathrm{ppm}): 7.08-7.24$ $(6 \mathrm{H}, \mathrm{m}, \mathrm{ArH}), \quad 6.15(\mathrm{~m}, 1 \mathrm{H}$, (furan $\mathrm{C}-\mathrm{CH}) ; 5.67(1 \mathrm{H}, \mathrm{m}$, $\left.\mathrm{CH}_{\text {isoxazoline }}\right), 3.65\left(1 \mathrm{H}, \mathrm{dd}, J=11.7,5.6 \mathrm{~Hz}, \mathrm{CH}_{\text {isoxazoline }}\right), 3.58(1 \mathrm{H}$, $\mathrm{dd}, J=9.7,7.9 \mathrm{~Hz}, \mathrm{CH}_{\text {isoxazoline}) ; ~}{ }^{13} \mathrm{CNMR}$ (DMSO- $\left.d_{6}\right) \delta(\mathrm{ppm})$ : 150.0, 145.4, 139.4, 132.4, 128.7, 124.7, 122.2, 116.0, 115.2, 79.2, 42.9. MS: $\mathrm{m} / \mathrm{z} 292\left(\mathrm{M}^{+}\right)$and $294(\mathrm{M}+2)$. Elemental analysis: Calculated for $\mathrm{C}_{13} \mathrm{H}_{10} \mathrm{BrNO}_{2}: \mathrm{C}, 53.45 ; \mathrm{H}, 3.45 ; \mathrm{N}, 4.79$; found: $\mathrm{C}$, 
$53.57 ; \mathrm{H}, 3.54 ; \mathrm{N}, 4.86 \%$.

\section{5-(4-Fluorophenyl)-3-(furan-2-yl)-4,5-dihydro-1,2-oxazole (2d)}

Yield 58\%; m.p. $112{ }^{\circ} \mathrm{C}$. FTIR ( $\mathrm{KBr}$ pellet) $\mathrm{cm}^{-1}: 1661(\mathrm{C}=\mathrm{N}), 1357$ $(\mathrm{C}-\mathrm{O}-\mathrm{N}), 1057$ (C-O-C). ${ }^{1} \mathrm{H}$ NMR (DMSO-d $) \delta$ (ppm): 7.11-7.28 $(6 \mathrm{H}, \mathrm{m}, \mathrm{ArH}), \quad 6.17(\mathrm{~m}, 1 \mathrm{H}$, (furan $\mathrm{C}-\mathrm{CH}) ; 5.73(1 \mathrm{H}, \mathrm{m}$, $\left.\mathrm{CH}_{\text {isoxazoline }}\right), 3.65\left(1 \mathrm{H}, \mathrm{dd}, J=11.7,5.7 \mathrm{~Hz}, \mathrm{CH}_{\text {isoxazoline }}\right), 3.61(1 \mathrm{H}$, $\left.\mathrm{dd}, J=9.4,7.7 \mathrm{~Hz}, \mathrm{CH}_{\text {isoxazoline }}\right) ;{ }^{13} \mathrm{CNMR}$ (DMSO- $\left.d_{6}\right) \delta(\mathrm{ppm})$ : 159.4, 150.0, 145.4, 139.0. 127.7, 122.2, 116.0, 115.6, 115.2, 79.2, 42.9. MS: $\mathrm{m} / \mathrm{z} 231(\mathrm{M}+)$. Elemental analysis: Calculated for $\mathrm{C}_{13} \mathrm{H}_{10} \mathrm{FNO}_{2}$ : C, 67.53; $\mathrm{H}, 4.36$; N, 6.06; found: $\mathrm{C}, 67.62 ; \mathrm{H}, 4.45 ; \mathrm{N}$, $6.14 \%$.

\section{4-[3-(Furan-2-yl)-4,5-dihydro-1,2-oxazol-5-yl]phenol (2e)}

Yield 64\%; m.p. $126^{\circ} \mathrm{C}$. FTIR (KBr pellet) $\mathrm{cm}^{-1}: 1651(\mathrm{C}=\mathrm{N}), 1357$ $(\mathrm{C}-\mathrm{O}-\mathrm{N}), 1049$ (C-O-C). ${ }^{1} \mathrm{H}$ NMR (DMSO-d $) \delta$ (ppm): 6.75-7.26 $(6 \mathrm{H}, \mathrm{m}, \mathrm{ArH}), 6.13(\mathrm{~s}, 1 \mathrm{H}, \mathrm{Ar}-\mathrm{OH}), 6.12(\mathrm{~m}, 1 \mathrm{H}$, (furan $\mathrm{C}-\mathrm{CH})$; $5.80\left(1 \mathrm{H}, \mathrm{m}, \mathrm{CH}_{\text {isoxazoline }}\right), 3.59(1 \mathrm{H}, \mathrm{dd}, J=11.3,5.7 \mathrm{~Hz}$, $\left.\mathrm{CH}_{\text {isoxazoline }}\right), 3.58\left(1 \mathrm{H}, \mathrm{dd}, J=9.6,7.6 \mathrm{~Hz}, \mathrm{CH}_{\text {isoxazoline}}\right) ;{ }^{13} \mathrm{CNMR}$ $\left(\mathrm{DMSO}-d_{6}\right) \delta(\mathrm{ppm}): 157.8,150.0,145.4,139.4,129.8,118.9$, 118.2, 116.0, 115.2, 79.0, 42.9. MS: m/z 229 (M+). Elemental analysis: Calculated for $\mathrm{C}_{13} \mathrm{H}_{11} \mathrm{NO}_{3}$ : C, 68.11; $\mathrm{H}, 4.84 ; \mathrm{N}, 6.11$; found: $\mathrm{C}, 68.22 ; \mathrm{H}, 4.92 ; \mathrm{N}, 6.18 \%$.

\section{3-(Furan-2-yl)-5-(4-methylphenyl)-4,5-dihydro-1,2-oxazole (2f)}

Yield 54\%; m.p. $138^{\circ} \mathrm{C}$. FTIR (KBr pellet) $\mathrm{cm}^{-1}: 1656(\mathrm{C}=\mathrm{N}), 1352$ $(\mathrm{C}-\mathrm{O}-\mathrm{N}), 1052$ (C-O-C). ${ }^{1} \mathrm{H}$ NMR (DMSO- $\left.d_{6}\right) \delta(\mathrm{ppm}): 2.13(\mathrm{~s}, 3 \mathrm{H}$, Ar- $\left.\mathrm{CH}_{3}\right), 7.10-7.24(6 \mathrm{H}, \mathrm{m}, \mathrm{ArH}), 6.20(\mathrm{~m}, 1 \mathrm{H}$, (furan $\mathrm{C}-\mathrm{CH}) ; 5.81$ $\left(1 \mathrm{H}, \mathrm{m}, \mathrm{CH}_{\text {isoxazoline }}\right), 3.65\left(1 \mathrm{H}, \mathrm{dd}, J=11.6,5.8 \mathrm{~Hz}, \mathrm{CH}_{\text {isoxazoline }}\right)$, $3.57\left(1 \mathrm{H}, \mathrm{dd}, J=9.5,7.8 \mathrm{~Hz}, \mathrm{CH}_{\text {isoxazoline }}\right) ;{ }^{13} \mathrm{CNMR}$ (DMSO- $\left.d_{6}\right) \delta$ (ppm): 151.6, 149.2, 140.2, 138.8, 131.0, 129.5, 124.1, 114.5, 110.8, 79.2, 42.8, 20.6. MS: $\mathrm{m} / \mathrm{z} 227(\mathrm{M}+)$. Elemental analysis: Calculated for $\mathrm{C}_{14} \mathrm{H}_{13} \mathrm{NO}_{2}$ : C, 79.99; $\mathrm{H}, 5.77 ; \mathrm{N}, 6.16$; found: $\mathrm{C}$, 80.03; H, 6.23; N, 6.23\%.

\section{5-(4-Methoxyphenyl)-3-(furan-2-yl)-4,5-dihydro-1,2-oxazole (2g)}

Yield 58\%; m.p. $134-136^{\circ} \mathrm{C}$. FTIR ( $\mathrm{KBr}$ pellet) $\mathrm{cm}^{-1}: 1651(\mathrm{C}=\mathrm{N})$, 1357 (C-O-N), 1054 (C-O-C). ${ }^{1} \mathrm{H}$ NMR (DMSO-d $d_{6} \delta$ (ppm): 3.43 (s, 3H, Ar- $\left.\mathrm{OCH}_{3}\right), 6.87-7.29(6 \mathrm{H}, \mathrm{m}, \mathrm{ArH}), 6.10$ (m, $1 \mathrm{H}$, (furan C$\mathrm{CH}) ; 5.78\left(1 \mathrm{H}, \mathrm{m}, \mathrm{CH}_{\text {isoxazoline }}\right), 3.61(1 \mathrm{H}, \mathrm{dd}, J=11.3,5.7 \mathrm{~Hz}, \mathrm{CH})$, $3.59\left(1 \mathrm{H}, \mathrm{dd}, J=9.1,7.6 \mathrm{~Hz}, \mathrm{CH}_{\text {isoxazoline) }}{ }^{13} \mathrm{CNMR}\right.$ (DMSO- $\left.d_{6}\right) \delta$ (ppm): 151.7, 145.4, 139.4, 138.8, 131.0, 124.1, 129.5, 116.0, 115.2, 79.2, 46.8, 42.6. MS: $\mathrm{m} / \mathrm{z} 243(\mathrm{M}+)$. Elemental analysis: Calculated for $\mathrm{C}_{14} \mathrm{H}_{13} \mathrm{NO}_{3}$ : C, 69.12; $\mathrm{H}, 5.39 ; \mathrm{N}, 5.76$; found: $\mathrm{C}$, 69.23; H, 5.42; N, 5.84\%.

\section{4-[3-(Furan-2-yl)-4,5-dihydro-1,2-oxazol-5-yl]aniline (2h)}

Yield 56\%; m.p. $106^{\circ} \mathrm{C}$. FTIR (KBr pellet) $\mathrm{cm}^{-1}: 1658(\mathrm{C}=\mathrm{N}), 1357$ $(\mathrm{C}-\mathrm{O}-\mathrm{N}), 1055$ (C-O-C). ${ }^{1} \mathrm{H}$ NMR (DMSO- $\left.d_{6}\right) \delta(\mathrm{ppm}): 3.36(\mathrm{~s}, 2 \mathrm{H}$, Ar- $\left.\mathrm{NH}_{2}\right), \quad 6.50-7.07(6 \mathrm{H}, \mathrm{m}, \mathrm{ArH}), 6.08(\mathrm{~m}, 1 \mathrm{H}$, (furan $\mathrm{C}-\mathrm{CH}) ; 5.79$ $\left(1 \mathrm{H}, \mathrm{m}, \mathrm{CH}_{\text {isoxazoline }}\right), 3.63\left(1 \mathrm{H}, \mathrm{dd}, J=11.6,5.7 \mathrm{~Hz}, \mathrm{CH}_{\text {isoxazoline }}\right)$, $3.60\left(1 \mathrm{H}, \mathrm{dd}, J=9.5,7.6 \mathrm{~Hz}, \mathrm{CH}_{\text {isoxazoline }}\right) ;{ }^{13} \mathrm{CNMR}$ (DMSO- $\left.d_{6}\right) \delta$ (ppm): 150.6, 145.4, 145.3, 139.4, 127.2, 120.0, 116.4, 116.0, 115.2, 79.2, 42.9. MS: $\mathrm{m} / \mathrm{z} 228(\mathrm{M}+)$. Elemental analysis: Calculated for $\mathrm{C}_{13} \mathrm{H}_{12} \mathrm{~N}_{2} \mathrm{O}_{2}$ : C, 68.41; $\mathrm{H}, 5.30 ; \mathrm{N}, 12.27$; found: $\mathrm{C}$, 68.52; $\mathrm{H}, 5.41 ; \mathrm{N}, 12.34 \%$.

\section{N,N-Dimethyl-4-[3-(furan-2-yl)-4,5-dihydro-1,2-oxazol-5- yl]aniline (2i)}

Yield 62\%; m.p. $140^{\circ} \mathrm{C}$. FTIR ( $\mathrm{KBr}$ pellet) $\mathrm{cm}^{-1}: 1652(\mathrm{C}=\mathrm{N}), 1357$ (C-O-N), 1053 (C-O-C). ${ }^{1} \mathrm{H}$ NMR (DMSO- $\left.d_{6}\right) \delta(\mathrm{ppm}): 2.84(\mathrm{~s}, 6 \mathrm{H}$, Ar- $\left.\mathrm{N}-\left(\mathrm{CH}_{3}\right)_{2}\right), 6.44-7.08(6 \mathrm{H}, \mathrm{m}, \mathrm{ArH}), 6.12(\mathrm{~m}, 1 \mathrm{H}$, (furan $\mathrm{C}-\mathrm{CH})$; $5.80\left(1 \mathrm{H}, \mathrm{m}, \mathrm{CH}_{\text {isoxazoline }}\right), 3.65(1 \mathrm{H}, \mathrm{dd}, J=11.7,5.7 \mathrm{~Hz}$, $\left.\mathrm{CH}_{\text {isoxazoline }}\right), 3.60\left(1 \mathrm{H}, \mathrm{dd}, J=9.4,7.6 \mathrm{~Hz}, \mathrm{CH}_{\text {isoxazoline }}\right) ;{ }^{13} \mathrm{CNMR}$ $\left(\mathrm{DMSO}-d_{6}\right) \delta(\mathrm{ppm}): 151.3,148.3,145.4,139.4,128.8,118.6$ 116.0, 115.2, 113.4, 79.2, 42.9, 40.3. MS: m/z 256 (M+). Elemental analysis: Calculated for $\mathrm{C}_{15} \mathrm{H}_{16} \mathrm{~N}_{2} \mathrm{O}_{2}$ : C, 70.29; $\mathrm{H}, 6.29 ; \mathrm{N}, 10.93$; found: $\mathrm{C}, 70.33 ; \mathrm{H}, 6.36 ; \mathrm{N}, 10.98 \%$.

\section{5-(3,4-Dimethoxyphenyl)-3-(furan-2-yl)-4,5-dihydro-1,2-oxazole} (2j)

Yield 58\%; m.p. $125^{\circ} \mathrm{C}$. FTIR (KBr pellet) $\mathrm{cm}^{-1}: 1656(\mathrm{C}=\mathrm{N}), 1352$ $(\mathrm{C}-\mathrm{O}-\mathrm{N}), 1052$ (C-O-C). ${ }^{1} \mathrm{H}$ NMR (DMSO- $\left.d_{6}\right) \delta(\mathrm{ppm}): 3.85(\mathrm{~s}, 6 \mathrm{H}$, $\left.\operatorname{Ar}-\left(\mathrm{OCH}_{3}\right)_{2}\right), \quad 6.44-7.07(5 \mathrm{H}, \mathrm{m}, \mathrm{ArH}), \quad 6.11(\mathrm{~m}, 1 \mathrm{H}$, (furan $\mathrm{C}-\mathrm{CH})$; $5.80\left(1 \mathrm{H}, \mathrm{m}, \mathrm{CH}_{\text {isoxazoline }}\right), 3.65(1 \mathrm{H}, \mathrm{dd}, J=11.6,5.8 \mathrm{~Hz}$, $\left.\mathrm{CH}_{\text {isoxazoline }}\right), 3.57\left(1 \mathrm{H}, \mathrm{dd}, J=9.4,7.6 \mathrm{~Hz}, \mathrm{CH}_{\text {isoxazoline }}\right) ;{ }^{13} \mathrm{CNMR}$ $\left(\right.$ DMSO- $\left.d_{6}\right) \delta(\mathrm{ppm}): 150.0,149.8,148.2,145.4,139.4,130.5$, 121.3, 116.0, 115.2, 113.5, 110.2, 80.3, 56.0, 42.8. MS: $\mathrm{m} / \mathrm{z} 273$ $(\mathrm{M}+)$. Elemental analysis: Calculated for $\mathrm{C}_{15} \mathrm{H}_{15} \mathrm{NO}_{4}: \mathrm{C}, 65.92 ; \mathrm{H}$, 5.53; N, 5.13; found: C, 65.98; H, 5.62; N, 5.23\%.

\section{Pharmacological screening}

\section{Antidepressant activity (Forced swim test in mice)}

Behavioral despair or forced swim test (FST) was proposed as a model to test antidepressant activity by Porsolt et al. (1977). It was suggested that mice or rats when forced to swim in restricted space from where they cannot escape are induced to a characteristic behavior of immobility. This behavior reflects a state of despair which can be reduced by several agents which are therapeutically effective in human depression. The behavioral despair test is employed to assess the antidepressant activity of synthesized derivatives. Albino mice of 20 to $25 \mathrm{~g}$ in a group of six each were used and on the first day of the experiment (pretest session), mice were individually placed in a cylindrical recipient (Plexiglass cylinder) of dimensions (diameter, $10 \mathrm{~cm}$; height, $25 \mathrm{~cm}$ ) containing $10 \mathrm{~cm}$ of water $25^{\circ} \mathrm{C}$. The animals were left to swim for $6 \mathrm{~min}$ before being removed, dried and returned to their cages. The procedure was repeated $24 \mathrm{~h}$ later, in $5 \mathrm{~min}$ swim session (test session). The synthesized compounds (10 $\left.\mathrm{mg} \mathrm{kg}^{-1}\right)$, and imipramine, as a reference antidepressant drug $\left(10 \mathrm{mg} \mathrm{kg}^{-1}\right)$ were suspended in a $1 \%$ aqueous solution of Tween 80 . The drugs were injected intraperitoneally (ip) in a standard volume of $0.5 \mathrm{ml} / 20 \mathrm{~g}$ body weight, $1 \mathrm{~h}$ prior to the test. Control animals received $1 \%$ aqueous solution of Tween 80 . Then, the mice were dropped individually into the Plexiglass cylinder and left in the water for 6 min. After the first $2 \mathrm{~min}$ of the initial vigorous struggling, the animals were immobile. A immobility time is the time spent by mice floating in water without struggling, making only those moment necessary to keep the head above the water. The total duration of immobility was recorded during the last $4 \mathrm{~min}$ of the 6 min test session.

\section{MAO inhibition}

The synthesized compounds $2 b, 2 d, 2 e$, and $2 f$ tested to determine their activity toward MAO rat brain mitochondria were isolated according to (Basford et al., 1967; Johnston et al., 1968). The inhibitory effects of compounds on MAO were determined using a 
fluorimetric method as described by Matsumoto et al. (1985), Weissbach et al. (1960) and Knoll et al. (1972). The mitochondrial fractions were incubated at $38^{\circ} \mathrm{C}$ for 30 min with the substrate. The incubation mixture containing $0.1 \mathrm{ml}$ phosphate buffer $(0.25 \mathrm{M}, \mathrm{pH}$ $7.4)$, mitochondrial suspension $(6 \mathrm{mg} / \mathrm{ml})$, the substrate $(0.1 \mathrm{mM})$ and test compounds at five different concentrations ranging from $0.5 \mathrm{nM}$ to $0.1 \mathrm{M}(0,0.5 \mathrm{nM}, 5 \mathrm{nM}, 5 \mathrm{mM}, 5 \mathrm{mM}$ and $100 \mathrm{mM})$ were dissolved in propylene glycol. The mixture was incubated at $37^{\circ} \mathrm{C}$ for $60 \mathrm{~min}$ and inhibition was quenched by adding perchloric acid. The samples were centrifuged at $10,000 \mathrm{~g}$ for $5 \mathrm{~min}$ and the supernatant was completed to $2.7 \mathrm{ml}$ using $1 \mathrm{~N} \mathrm{NaOH}$ and measured with a Spectrofluorimeter (RF-5301PC Shimadzu). The values were from 3 independent samples that were measured in duplicate. The average value of the duplicate measurements was used for the statistical analysis. Protein concentration was determined according to a previously reported method. The MAO results are expressed as percent inhibition (Table 2 ).

\section{Docking studies}

Docking studies were performed using Glide module of the Schrodinger-9 software on the falcipain-2 receptor (PDB id: $2 Z 5 X$ ). Receptor preparation was done using protein preparation wizard using defaults options and the final root-mean-square deviation (RMSD) was used as $<30 \AA$. The structures were sketched in maestro graphical user interface and were energy minimized/cleaned up by Lig prep module of same software using OPLS_2005 force field and proper protonation states were assigned with the ionizer subprogram at $\mathrm{pH} 7.2 \pm 0.2$ (Lig Prep 2009). A grid of $20 \AA$ was set for the docking calculations. Glide XP module was used for final docking studies (Glide, 2009).

\section{Antianxiety activity}

Elevated plus maze apparatus for mice (Moser, 1989; Rabbani et al., 2004; Pellow et al., 1985; Kulkarni, 2002; Sienkiewicz et al., 2003) consisted of two open $\left(16 \times 5 \mathrm{~cm}^{2}\right)$ and two closed arms $(16$ $\times 5 \times 12 \mathrm{~cm}^{3}$ ) facing each other with an open roof. The entire maze is elevated of a height of $25 \mathrm{~cm}$. Concentration of each compounds $(10 \mathrm{mg} / \mathrm{kg})$ were used in the form of suspensions in $1 \%$ tween 80 . All solutions were prepared freshly on test days and given intraperitoneally (ip) in a volume of $2 \mathrm{ml} / \mathrm{kg}$ body weight of mice. The experimental animals were treated with Diazepam $(2 \mathrm{mg} / \mathrm{kg}, \mathrm{n}$ $=6$ ), or the compounds $(10 \mathrm{mg} / \mathrm{kg}) 60 \mathrm{~min}$ before evaluation in the maze. The control group was given saline with $1 \%$ tween 80 . Test begun with the mice placed singly in the center of plus-maze facing one open arm. The number of entries and the time spent in closed and open arms was recorded for 5 min. Entry into an arm was defined as the animal placing all four paws onto the arm. Total exploratory activity (number of entries, time spent in open and closed arms) were also registered. After each test, the maze was carefully cleaned up with a wet tissue paper (10\% ethanol solution). Groups of six male albino mice (20 to $24 \mathrm{~g}$ ) were conditioned to laboratory environment ( $12 \mathrm{~h}$ light and $12 \mathrm{~h}$ dark), with free access to water and food. Data obtained in the test were compared against the control group by using the ANOVA method and followed by a post Dunnett test. The results of elevated plus maze (EPM )have been summarized in Table 3 .

\section{Neurotoxicity (NT)}

Assessment of motor coordination in Rota-Rod test was used to evaluate NT. With the aim of investigating test compounds induced any changes in motor coordination of the animals, Rota-Rod test was performed. The animal was placed on a 1 inch diameter knurled wooden rod rotating at $6 \mathrm{rpm}$. Normal mice remain on a rod rotating at this speed indefinitely. Neurologic toxicity was defined as the failure of the animal to remain on the rod for $1 \mathrm{~min}$.

\section{Statistical analyses}

The obtained experimental data were analyzed by one way analysis of variance (ANOVA) followed by Dunnet's test and were used to evaluate the results, using InStat Graph Pad (version 3.06, Graph Pad Software Inc., San Diego, CA, USA). The results are expressed as mean + Standard error of mean (SEM); $n$ represents the number of animals. Differences between data sets were considered as significant when $p$ value was less than 0.05 .

\section{RESULTS AND DISCUSSION}

\section{Chemistry}

As shown in Figure 1, the intermediate chalcones $1 \mathrm{a}$ to $\mathrm{j}$ was synthesized by Claisen-Schmidt condensation of 2acetyl furan and the appropriate substituted aromatic aldehydes. Cyclization of $1 \mathrm{a}$ to $\mathrm{j}$ with hydroxylamine hydrochloride in the presence of dry pyridine afforded $2 \mathrm{a}$ to $j$. The structures of the new compounds $2 a$ to j were confirmed by elemental analyses and spectral data. The physical constants of isoxazoline derivatives (2a-j) are shown in (Table 1). The IR spectrum of compound $2 \mathrm{a}$ showed absorption peak at $1352 \mathrm{~cm}^{-1}$ due to $\mathrm{C}-\mathrm{O}$ and $1656 \mathrm{~cm}^{-1}$ for $\mathrm{C}=\mathrm{N}$ stretching vibrations. The structure was further conformed by its ${ }^{1} \mathrm{H}$ NMR spectrum, which showed two double doublet at $\delta 3.62$ and 3.59 for $\mathrm{CH}_{2}$ protons of isoxazoline ring. The $\mathrm{CH}$ proton at $\mathrm{C}-5$ of isoxazoline was obtained as a multiplet at $\delta 5.78$. Thus, disappearance of signals of the olefinic protons and appearance of $\mathrm{CH}_{2}$ and $\mathrm{CH}$ proton signals in the spectrum confirmed the formation of isoxazoline ring. The mass spectrum of the compound $2 \mathrm{a}$ showed molecular ion peak $\mathrm{M}^{+}$at $\mathrm{m} / \mathrm{z} 213$ corresponding to molecular formula $\mathrm{C}_{13} \mathrm{H}_{11} \mathrm{NO}_{2}$.

\section{Pharmacological activity}

All the synthesized compounds were tested in vivo in order to evaluate their antidepressant and antianxiety activity. The pharmacological data of all the compounds is reported in Table 3. These compounds when screened for their antidepressant activity by forced swimming test at $10 \mathrm{mg} \mathrm{kg}^{-1}$ i.p., exhibited substantive antidepressant activity. All the substitutions were made at the phenyl ring to evaluate their structural activity relationship. The results of antidepressant activity showed that compounds having electron releasing groups at the para position of phenyl ring like $2 \mathrm{~g}\left(\mathrm{p}-\mathrm{OCH}_{3}\right), 2 \mathrm{~h}\left(\mathrm{p}-\mathrm{NH}_{2}\right), 2 \mathrm{i}(\mathrm{p}-\mathrm{N}, \mathrm{N}-$ $\left.\left(\mathrm{CH}_{3}\right)_{2}\right)$ and 2j $\left(\mathrm{m}, \mathrm{p}-\left(\mathrm{OCH}_{3}\right)_{2}\right)$ moderately decreased the immobility time (from -1.96 to $-3.15 \%$ ). However, para substituted derivatives having electron withdrawing groups significantly decreased the immobility time with respect to control. For example, compounds $2 b(p-C l$, - 
Table 1. Physicochemical parameters of the synthesized compounds (2a-j).

\begin{tabular}{cccccc}
\hline Compound & $\mathbf{R}$ & Molecular formula & Molecular weight & Yield (\%) & Melting Point ( $\left.{ }^{\circ} \mathbf{C}\right)$ \\
\hline $2 \mathrm{a}$ & $\mathrm{H}$ & $\mathrm{C}_{13} \mathrm{H}_{11} \mathrm{NO}_{2}$ & 213.23 & 58 & 112 \\
$2 \mathrm{~b}$ & $4-\mathrm{Cl}$ & $\mathrm{C}_{13} \mathrm{H}_{10} \mathrm{ClNO}_{2}$ & 247.67 & 65 & 142 \\
$2 \mathrm{c}$ & $4-\mathrm{Br}$ & $\mathrm{C}_{13} \mathrm{H}_{10} \mathrm{BrNO}_{2}$ & 292.12 & 57 & 98 \\
$2 \mathrm{~d}$ & $4-\mathrm{F}$ & $\mathrm{C}_{13} \mathrm{H}_{10} \mathrm{FNO}_{2}$ & 231.22 & 60 & 115 \\
$2 \mathrm{e}$ & $4-\mathrm{OH}$ & $\mathrm{C}_{13} \mathrm{H}_{11} \mathrm{NO}_{3}$ & 229.23 & 64 & 126 \\
$2 \mathrm{f}$ & $4-\mathrm{CH}$ & $\mathrm{C}_{14} \mathrm{H}_{13} \mathrm{NO}_{2}$ & 227.25 & 54 & 138 \\
$2 \mathrm{~g}$ & $4-\mathrm{OCH}_{3}$ & $\mathrm{C}_{14} \mathrm{H}_{13} \mathrm{NO}_{3}$ & 243.25 & 58 & $134-136$ \\
$2 \mathrm{~h}$ & $4-\mathrm{NH}_{2}$ & $\mathrm{C}_{13} \mathrm{H}_{12} \mathrm{~N}_{2} \mathrm{O}_{2}$ & 228.24 & 56 & 106 \\
$2 \mathrm{i}$ & $4-\mathrm{N}\left(\mathrm{CH}_{3}\right)_{2}$ & $\mathrm{C}_{16} \mathrm{H}_{18} \mathrm{~N}_{2} \mathrm{O}_{2}$ & 270.32 & 62 & 140 \\
$2 \mathrm{j}$ & $3,4-\left(\mathrm{OCH}_{3}\right)_{2}$ & $\mathrm{C}_{15} \mathrm{H}_{15} \mathrm{NO}_{4}$ & 273.28 & 58 & 125 \\
\hline
\end{tabular}

Table 2. Antidepressant activity, neurotoxicity of the newly synthesized compounds and in vitro MAO inhibition activity on rat brain mitochondria by kynuramine fluorimetric assay.

\begin{tabular}{|c|c|c|c|c|}
\hline \multirow[b]{2}{*}{ Compound } & \multicolumn{2}{|c|}{ Antidepressant activity (FST) } & \multirow{2}{*}{$\begin{array}{c}\text { MAO Inhibition } \\
\text { Monoamine oxidase } \\
\text { inhibition }^{\mathrm{a}}(\%)\end{array}$} & \multirow{2}{*}{$\begin{array}{c}\text { Neurotoxicity } \\
\begin{array}{c}\text { Coordination time in s } \\
\text { (mean } \pm \text { SEM) }\end{array}\end{array}$} \\
\hline & $\begin{array}{l}\text { Immobility time (s) } \\
(\text { mean } \pm \text { SEM) }\end{array}$ & $\begin{array}{l}\text { Change from control } \\
(\%)\end{array}$ & & \\
\hline $2 a$ & $162.83 \pm 0.60^{\star \star}$ & -1.64 & $\mathrm{Nt}$ & $\mathrm{Nt}$ \\
\hline $2 b$ & $155.66 \pm 0.33^{\star *}$ & -5.95 & $35.50 \pm 0.42$ & $58.00 \pm 0.57$ \\
\hline $2 c$ & $158.50 \pm 0.42^{\star *}$ & -4.23 & $\mathrm{Nt}$ & $46.16 \pm 0.47$ \\
\hline $2 d$ & $154.33 \pm 0.42^{\star *}$ & -6.75 & $39.50 \pm 0.76$ & $59.83 \pm 0.60$ \\
\hline $2 e$ & $153.16 \pm 0.30^{\star *}$ & -7.46 & $47.33 \pm 0.49$ & $62.00 \pm 0.57$ \\
\hline $2 f$ & $161.83 \pm 0.60^{* *}$ & -2.22 & $22.33 \pm 0.42$ & $47.16 \pm 0.60$ \\
\hline $2 g$ & $163.33 \pm 0.33^{*}$ & -1.31 & $\mathrm{Nt}$ & $49.66 \pm 0.66$ \\
\hline $2 \mathrm{~h}$ & $162.83 \pm 0.47^{\star \star}$ & -1.61 & $\mathrm{Nt}$ & $44.50 \pm 0.92$ \\
\hline $2 i$ & $163.16 \pm 0.54^{*}$ & -1.41 & $\mathrm{Nt}$ & $\mathrm{Nt}$ \\
\hline $2 \mathrm{j}$ & $163.83 \pm 0.47^{\mathrm{ns}}$ & -1.01 & $\mathrm{Nt}$ & $\mathrm{Nt}$ \\
\hline Imipramine & $149.00 \pm 0.57^{\star *}$ & -9.97 & $\mathrm{Nt}$ & $\mathrm{Nt}$ \\
\hline Control & $165.50 \pm 0.42$ & 0.0 & $\mathrm{Nt}$ & $\mathrm{Nt}$ \\
\hline Tranylcypro mine ${ }^{b}$ & $\mathrm{Nt}$ & $\mathrm{Nt}$ & $84.50 \pm 0.76$ & $\mathrm{Nt}$ \\
\hline
\end{tabular}

${ }^{a}$ Each value is the mean from three separate experiments with SE of mean. All compounds were used at a final concentration of $5 \times 10^{-4} \mathrm{M}$. ${ }^{b}$ Concentration of tranylcypromine used $5.0 \times 10^{-6} \mathrm{M}$. Values represent the mean \pm SEM $(n=6)$. *Significantly compared to control (Dunnet's test; $\mathrm{p}<0.05)$. ${ }^{* *}$ Significantly compared to control (Dunnet's test; $\left.\mathrm{p}<0.01\right)$. ns = denotes not Significantly compared to control and $\mathrm{Nt}=$ denotes not tested

Table 3. Anti anxiety activity of the newly synthesized compounds (Elevated plus maze test in mice).

\begin{tabular}{|c|c|c|c|}
\hline \multirow[b]{2}{*}{ Compound } & \multirow[b]{2}{*}{ Preference to open arm (\%) } & \multicolumn{2}{|c|}{ Open arm } \\
\hline & & $\begin{array}{l}\text { No. of entries } \\
\text { (mean } \pm \text { SEM) }\end{array}$ & $\begin{array}{c}\text { Average time spent } \\
\text { (mean } \pm \text { SEM) }\end{array}$ \\
\hline $2 a$ & 10.96 & $3.16 \pm 0.30$ & $32.00 \pm 0.57^{\star *}$ \\
\hline $2 b$ & 12.36 & $3.33 \pm 0.42$ & $35.83 \pm 0.60^{* *}$ \\
\hline $2 c$ & 13.62 & $3.00 \pm 0.25$ & $38.83 \pm 0.60^{\star *}$ \\
\hline $2 d$ & 15.58 & $5.16 \pm 0.47$ & $45.50 \pm 0.42^{* *}$ \\
\hline $2 e$ & 15.86 & $5.50 \pm 0.42$ & $46.00 \pm 0.57^{* *}$ \\
\hline $2 f$ & 15.22 & $4.50 \pm 0.42$ & $43.83 \pm 0.60^{* *}$ \\
\hline $2 g$ & 15.40 & $4.16 \pm 0.47$ & $44.50 \pm 0.76^{\star \star}$ \\
\hline $2 \mathrm{~h}$ & 10.43 & $3.33 \pm 0.42$ & $29.00 \pm 0.57^{\star *}$ \\
\hline $2 \mathrm{i}$ & 14.69 & $4.66 \pm 0.33$ & $42.00 \pm 0.57^{\star *}$ \\
\hline $2 \mathbf{j}$ & 9.93 & $2.16 \pm 0.30$ & $28.00 \pm 0.57^{\star \star}$ \\
\hline Control & 5.88 & $2.00 \pm 0.25$ & $16.16 \pm 0.47$ \\
\hline Diazepam (2 mg kg-1, ip) & 18.10 & $4.66 \pm 0.42$ & $52.50 \pm 0.42^{\star *}$ \\
\hline
\end{tabular}

Values represent the mean \pm SEM $(n=6)$. ${ }^{*}$ Significantly compared to control (Dunnet's test; $\left.p<0.01\right)$. 
<smiles>[R]c1cccc(C=O)c1</smiles><smiles>[R]c1ccc(C=CC(=O)c2ccco2)cc1</smiles>

$(\mathbf{a}-\mathbf{j})$

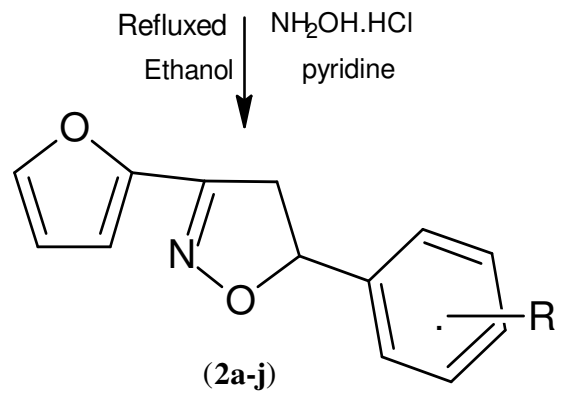

Figure 1. (furan-2-yl)-5-(substituted phenyl)-4,5-dihydro-1,2-oxazole derivatives (2a to j).
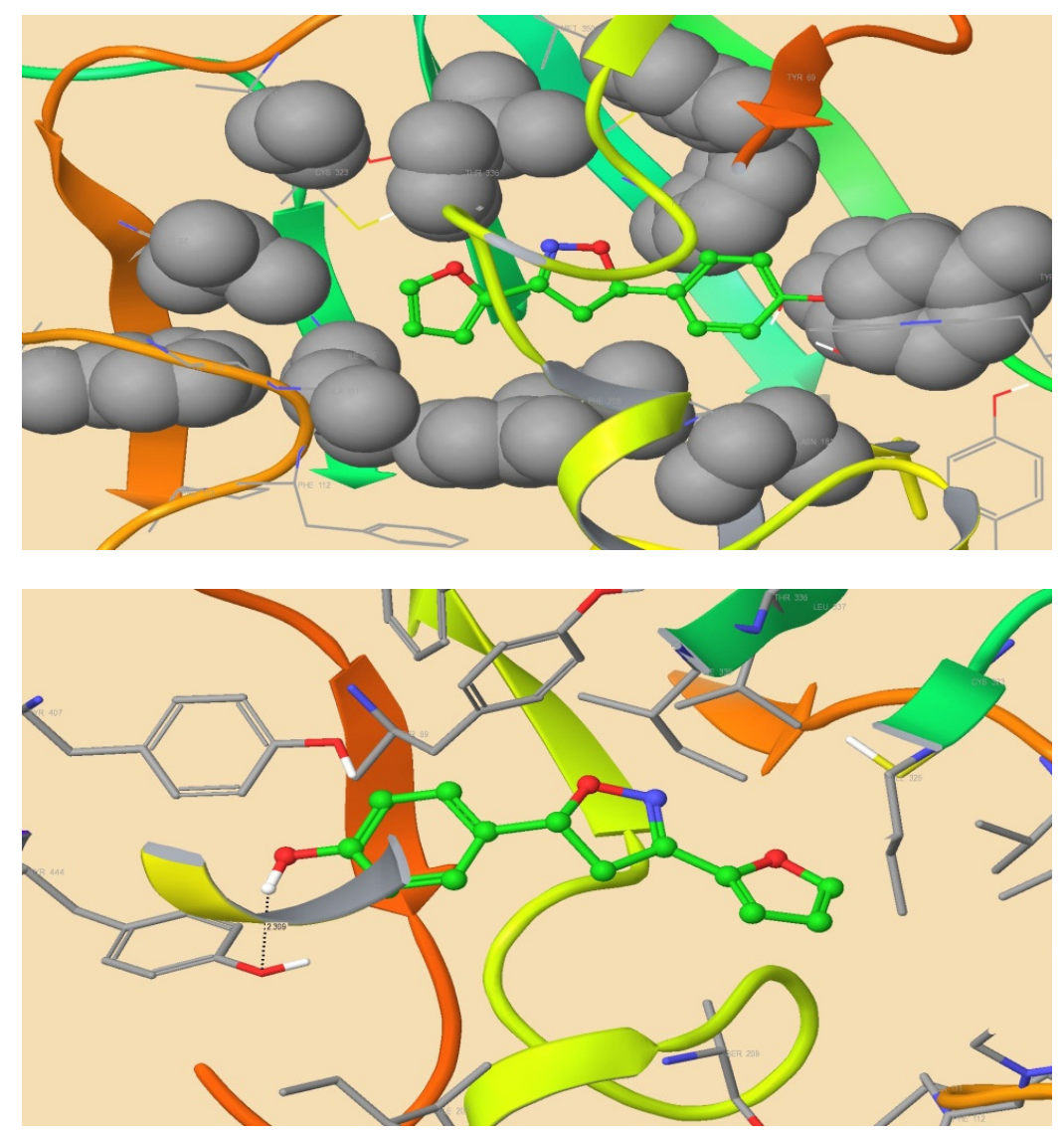

Figure 2. H-Bond docking pose of compound 2e on the falcipain-2 receptor (PDB id: 2Z5X).

$7.71 \%), 2 c(p-B r,-5.92 \%), 2 d(p-F,-9.00 \%)$ and $2 e(p-$ $\mathrm{OH},-10.58)$, were the most active antidepressant agents. Some of the compounds like $2 \mathrm{a}$ and $\mathrm{p}-\mathrm{CH}_{3}$ (2f) substituted derivatives also showed good antidepressant activity. The preliminary structure:activity relationship (SAR) for this particular isoxazoline series suggest that substitution of electron withdrawing group at the para position of phenyl ring results in increase in antidepressant 
activity while substitution with electron releasing group led to compounds having low antidepres-sant activity. Based on the promising antidepressant activities of the isoxazoline derivatives, some selected compounds were also evaluated for their MAO inhibitory effects by kynuramine fluorimetric assay method. Results of MAO inhibition study in Table 2 revealed that test compounds $2 b, d$, e and f produce weak to moderate MAO inhibition ranging between(22.33 and $47.33 \%$ at a final concentration of $5 \times 10^{-4} \mathrm{M}$ and maximum inhibition of $47.33 \%$ was obtained from compound $2 e$ as compared to standard tranylcypromine $84.50 \%$. Thus, indicating that the antidepressant activity of isoxazoline derivatives could be due to MAO inhibitory activity. These compounds were also evaluated for their motor coordination test by rotarod method to assess their neurotoxicity. The results of rotarod test indicated that none of the compound was neurotoxic at highest dose of $10 \mathrm{mg} / \mathrm{kg}$ (ip) as compared to standard drug imipramine. The compound $2 e$ showed very good binding and prominent interactions on the falcipain-2 receptor (PDB id: 2Z5X). The compound $2 \mathrm{e}$ is well occupied in the receptor cavity and forms hydrogen bond and hydrophobic interactions (Figure 2).

The anxiolytic activity of the synthesized compounds was evaluated in vivo in mice by elevated plus maze test. The tested compounds showed anxiolytic activity ranging from 9.93 to $15.86 \%$ preference to open arm, whereas diazepam showed $18.10 \%$ preference to open arm (Table 3). Among 10 compounds ( $2 a$ to j), six compounds ( $2 c, d$, $e, f, g$ and i) showed better antianxiety activity when compared with standard diazepam. It was found that compound $2 \mathrm{e}$ possess both antidepressant and antianxiety activities. This compound could be further investigated as a new possible candidate in the treatment of anxiolytics and antidepressants.

\section{Conclusion}

A series of 3-(furan-2-yl)-5-(substituted phenyl)-4,5dihydro-1,2-oxazole derivatives (2a to j) were synthesized as antidepressant and antianxiety agents. Out of these, 4-[3-(furan-2-yl)-4,5-dihydro-1,2-oxazol-5-yl]phenol (2e) emerged as the most potent antidepressant agent acting through MAO inhibition without any significant neurotoxicity. The observed MAO inhibitory action could also be responsible for its promising antianxiety effects.

\section{ACKNOWLEDGEMENTS}

The authors are grateful to Vice Chancellor, Jamia Hamdard for providing necessary facility and CDRI Lucknow for providing mass spectral data. One of the authors Mr. Jagdish Kumar Arun thank the University Grants Commission (UGC), New Delhi, for providing him RGN-SRF.

\section{REFERENCES}

Amrein R, Martin JR, Cameron AM (1999). Moclobemide in patients with dementia and depression. Adv. Neurol. 80:509-519.

Andersen SL, Teicher MH (2008). Stress, sensitive periods and maturational events in adolescent depression. Trends Neurosci. 4:183-191.

Andres JI, Alcazar J, Alonso JM, Alvarez RM, Bakker MH, Biesmans I, Cid JM, Lucas AID, Drinkenburg W, Fernández J, Font LM, Iturrino L, Langlois X, Lenaerts I, Martínez S, Megens AA, Pastor J, Pullan S, Steckler T (2007). Tricyclic isoxazolines: Identification of R226161 as a potential new antidepressant that combines potent serotonin reuptake inhibition and $\alpha_{2}$-adrenoceptor antagonism. Bioorg. Med. Chem. 15:3649-3660.

Balalaie S, Sharifi A, Ahangarian B (2000). Solid phase synthesis of isoxazole and pyrazole derivatives under microwave irradiation. Indian J. Heterocycl. Chem. 10:149-150.

Basford RE (1967). Preparation and properties of brain mitrochondria. Methods Enzymol. 10:96-101.

Cesura AM, Pletscher A (1992). The new generation of monoamine oxidase inhibitors. Prog. Drug Res. 38:171-297.

Chen YL, Zhao YL, Lu CM, Tzenga CC, Wang JP (2006). Synthesis, cytotoxicity, and anti-inflammatory evaluation of 2-(furan-2-yl)-4(phenoxy)quinoline derivatives. Part 4 Bioorg. Med. Chem. 14:43734378.

Crowley JJ, Lucki I (2005). Opportunities to discover genes regulating depression and antidepressant response from rodent behavioral genetics. Curr. Pharm. Des. 11:157-169.

Dannahardt G, Kiefer W, Kramer G, Maehrlein S, Nowe U, Fiebich B (2000). The Pyrrole Moiety as a Template for COX-1/COX-2 Inhibitors. Eur. J. Med. Chem. 35:499-510.

David SG, James TW, Michael WD, Jorge DB, Michael JB, James PS, George M C, Mark WH, Stephen PA, Michael W (1994). Novel Isoxazoles which Interact with Brain Cholinergic Channel Receptors Have Intrinsic Cognitive Enhancing and Anxiolytic Activities. J. Med. Chem. 37:1055-1059.

Deecher DC, Beyer CE, Johnston G, Bray J, Shah S, Abou-Gharbia M, Andree TH (2006). Desvenlafaxine succinate: A new serotonin and norepinephrine reuptake inhibitor. J. Pharmacol. Exp. Ther. 318(2):657-665.

Edwin W, Lilianna B (2004). Synthesis and pharmacological assessment of derivatives of isoxazolo[4,5-d]pyrimidine. Bioorg. Med. Chem. 12:265-272.

Fagervall I, Ross SB (1986). Inhibition of monoamine oxidase in monoaminergic neurones in the rat brain by irreversible inhibitors. Biochem. pharmacol. 35:1381-1387.

Gartside S, Cowen P (2006). Pharmacology of drugs used in the treatment of mood disorders. Psychiatry 5:162-166.

Gil JIA, Fernandez GEJ, Alcazar VMJ (Janssen Pharmaceutica NV, Belgium), (2002). PCT Int. Appl. W00266, 484: Chem. Abstr. 134:201298z.

Glide (2009) version 5.5, Schrödinger, LLC, New York, NY.

Henn FA, Vollmayr B, Sartorius A (2004). Mechanisms of depression: the role of neurogenesis. Drug Discovery Today: Disease Mechanisms 1:407-411.

Huang JQ, Li LY, Dong WX, Weng ZJ, Jin H, Ni XL, Zhang SJ, Huang CF, Gu FH (2006). Synthesis and antidepressant activities of aryl alkanol piperazine derivatives. Chin. J. Med. Chem. 16: 270-276.

Ignacio J, Gil A (2007). Substituted amino isoxazoline derivatives and their use as antidepressants. United State Pat. US 7,265,103 B2

Ignacio J, Gil A (2004). Isoxazoline derivatives as antidepressants. United State Pat. US 0122037 A1

Ignacio J, Gil A (2008). Isoxazoline indole derivatives with an improved antipsychotic and anxiolytic activity. United State Pat. US 0113988 A1.

Jayaprakash V, Sinha BN, Ucar G, Ercan A (2008). Pyrazoline-based mycobactin analogues as MAO-inhibitors, Bioorg. Med. Chem. Let. 18:6362-6368.

Jayashankar B, Lokanath Rai KM, Baskaran N, Sathish HS (2009). Synthesis and pharmacological evaluation of 1,3,4-oxadiazole bearing bis(heterocycle) derivatives as anti-inflammatory and analgesic agents. Eur. J. Med. Chem. 44:3898-3902. 
Johnston JP (1968). Some observations upon a new inhibitor of monoamine oxidase in brain tissue. Biochem. Pharmacol. 7:12851297.

Karuppasamy M, Mahapatra M, Yabanoglu S, Ucar G, Sinha BN, Basu A, Mishra N, Sharon A, Kulandaivelu U, Jayaprakash V (2010). Development of selective and reversible pyrazoline based MAO-A inhibitors: Synthesis, biological evaluation and docking studies. Bioorg. Med. Chem. 18:1875-1881.

Kelekci NG, Ozgun SO, Ercan A, Yelekci K, Sibel SZ, Ucar G, Bilgin AA (2009). Synthesis and molecular modeling of some novel hexahydroindazole derivatives as potent monoamine oxidase inhibitors. Bioorg. Med. Chem. 17:6761-6772.

Knoll J, Magyar K (1972). Puzzling pharmacological effects of monoamine oxidase [MAO] inhibitors. Adv. Biochem. Psychopharmacol. 5:393-408.

Koksal M, Bilge SS (2007). Synthesis and Antidepressant-Like Profile of Novel 1-Aryl-3-[(4- benzyl)piperidine-1-yl]propane Derivatives. Arch. Pharm. Chem. Life Sci. 340:299-303.

Kulkarni SK (2002). Animals Behavioral Models for Testing Anti-Anxiety Agents. In: Hand book of Experimental Pharmacology, 3rd ed., Delhi, Vallabh Prakashan, 27-37.

Lee YS, Park SM, Kim BH (2009). Synthesis of 5-isoxazol-5-yl-2'deoxyuridines exhibiting antiviral activity against HSV and several RNA viruses. Bioorg. Med. Chem. Lett. 19:1126-1128.

Lig Prep (2009). version 2.3, Schrodinger, LLC, New York, NY.

Mary, Sheeja TL, Mathew A, Varkey J (2011). Design synthesis and pharmacological evalution of isoxazole analogues derived from natural piperine. Asian J. Pharm. Health Sci. 2:256-260.

Matsumoto T, Suzuki O, Furuta T, Asai M, Kurokawa Y, Rimura Y, Katsumata Y, Takahashi I (1985). A sensitive fluorometric assay for serum monoamine oxidase with kynuramine as substrate. Clin. Biochem. 18:126-129.

Maurya R, Ahmad A, Gupta P, Chand K, Kumar M, Jayendra, Rawat P, Rasheed N, Palit G (2011). Synthesis of novel isoxazolines via 1, 3-dipolar cycloaddition and evaluation of anti stress activity. Med. Chem. Res. 20:139-145.

Moser PC (1989). An evaluation of the elevated plus-maze test using the novel anxiolytic Buspiron. Psychopharmacology (Berl) 99:48-53.

Owen JCE, Whitton PS (2006). Chronic treatment with antidepressant drugs reversibly alters NMDA mediated regulation of extracellular 5HT in rat frontal cortex. Brain Res. Bull. 70:62-67.
Pellow S, Chopin P, File SE, Briley M (1985). Validation of open: closed arm entries in an elevated plus-maze as a measure of anxiety in the rats. J. Neurosci. 14:149-167.

Porsolt RD, Bertin A, Jalfre M (1977). Behavioral despair in mice: A primary screening test for antidepressants. Arch. Int. Pharmacodyn. Ther. 229:327-336.

Rabbani M, Sajjadi SE, Vaseghi G, Jafarian A (2004). Anxiolytic effects of Echium amoenum on the elevated plus maze model of anxiety in mice. Fitoterapia 75:475-464

Sanchez C (2006). Allosteric modulation of monoamine transporters new drug targets in depression Drug Discovery Today: Ther. Strategies 4:483-488.

Sienkiewicz-Jarosz H, Szyndler J, Członkowska Al, Siemiatkowski M, Maciejak $P$, Wisłowska $A$, Zienowicz M, Lehner M, Turzyńska D, Bidziński A, Płaźnik A (2003). Rat behavior in two models of anxiety and brain $[3 \mathrm{H}]$ muscimol binding: pharmacological, correlation, and multifactor analysis. Behav. Brain Res. 145:17-22.

Sun HL, Wanga TT, Lv ZL, Feng JL, Geng DP, Li YM, Li K, (2010). Synthesis, chiral resolution, and determination of novel furan lignin derivatives with potent anti-tumor activity. Bioorg. Med. Chem. Lett. 20:1961-1964.

Tangallapally RP, Lee REB, Lenaerts AJM, Leea RE (2006). Synthesis of new and potent analogues of anti-tuberculosis agent 5-nitro-furan2-carboxylic acid 4-(4-benzyl-piperazin-1-yl)- benzylamide with improved bioavailability. Bioorg. Med. Chem. Lett. 16:2584-2589.

Weissbach H, Smith TE, Daly JW, Witkop B, Udenfriend S (1960). A Rapid Spectrophotometric Assay of Monoamine Oxidase Based on the Rate of Disappearance of Kynuramine J. Biol. Chem. 235:11601163.

Winters G, Milan, Sala A, Monza (1985). Antiinflammatory and anxiolytic isoxazol-[5,4-B]pyridines. United State Patent, patent no. 4530927.

Zuhal O, Kandilci HB, Gumusxel B, Unsal C, Bilgin AA (2007). Synthesis and studies on antidepressant and anticonvulsant activities of some 3-(2-furyl)-pyrazoline derivatives. Eur. J. Med. Chem. 42:373-379. 